\title{
PENGARUH PENAMBAHAN LIMBAH KARET BAN LUAR PADA LAPIS TIPIS ASPAL PASIR (LATASIR) TERHADAP KARAKTERISTIK MARSHALL
}

\author{
Fakhrul Rozi Yamali \\ Dosen Fakultas Teknik Unbari \\ fakhrul_65@yahoo.co.id
}

\begin{abstract}
The mixture of asphalt sand or often called as LATASIR (a thin Layer of asphalt Sand) is often used on the streets as light as local roads or road environment, in order to restrain the rate of water so as not to enter into pores in it. This mixture consists only of fine aggregate or sand or a mixture of both, so of coarse aggregate is not found in its alloy, so have the resilience of the Groove (rutting) are low and cannot be used on roads with heavy traffic or the area slopes. To improve the quality of asphalt mixture Latasir then do the addition of waste tire rubber out of the motor. This research was conducted with the marshall test asphalt plan levels, with 7\%, 8\%, 9\%, 10\% and 11\% in advance. After obtained the value levels of Optimum Asphalt (KAO), then do the test with the addition of marshall rubber tyres outside the motor of 1\%, 2\%, 3\%, 4\% and 5\% against weight. The research results obtained a value of $9.8 \%, K A O$ then conducted testing of marshall by using a variation of the rubber tyres outside the motor changes characteristic of Marshall, the degree of suppleness and durability is better, but there is a cavity the air that many great VIM or value, so that the value of the VFA became small. From all levels of rubber in asphalt has a great degree of flexibility in rubber 3\%, but that filled the whole terms of the 2010 revision 3 technical specifications on levels of $1.5 \%$ rubber.
\end{abstract}

Keywords: Latasir Mixture, KAO, Waste Rubber Tyres Outside Motor, Marshall

\section{PENDAHULUAN}

Pembangunan infrastruktur berkembang sangat pesat khususnya pada bidang konstruksi. Bidang konstruksi jalan merupakan penunjang laju pertumbuhan ekonomi baik secara nasional maupun daerah yang terkait pada sektor transportasi darat. Pentingnya transportasi dalam pembangunan terlihat dari maraknya pembangunan jalan dan jembatan, peningkatan tersebut tidak hanya dari segi kuantitas saja, namun peningkatan dari segi kualitas juga terus dilakukan dengan berbagai teknologi baru. Para ahli konstruksi terus melakukan percobaan untuk mencari berbagai metode penerapan material yang baik dalam pembangunan konstruksi jalan raya, material aspal merupakan material yang sangat tinggi nilai cost nya dalam pembangunan jalan, berbagai jenis lapisan aspal diantaranya lapis permukaan (overlay) atau penambahan latasir untuk mengurangi air yang masuk ke celah-celah lapisan sebelumnya.

Campuran aspal pasir atau sering disebut LATASIR (Lapis Tipis Aspal Pasir) sering digunakan pada jalan-jalan sedang dan ringan seperti jalan lokal, jalan lingkungan, guna menahan laju air agar tidak masuk kedalam poripori didalamnya. Latasir juga dapat digunakan untuk melapis permukaan lantai jembatan beton semen. Campuran ini hanya terdiri dari agregat halus atau pasir atau campuran keduanya, kecuali kerikil atau batu pecah ukuran kecil. Campuran latasir mempunyai ketahanan alur (rutting) yang rendah dan tidak dapat digunakan pada jalan dengan lalu lintas berat atau daerah tanjakan. 
Tristianto (2011) menjelaskan penggunaan limbah karet ban luar pada campuran Latasir B memberikan pengaruh yang signifikan terhadap kualitas / karakteristik campuran latasir B. Limbah karet ban bekas yang sudah tidak terpakai sering kita temui pada tukang tambal ban motor atau mobil yang dibuang begitu saja dipinggir jalan. Limbah karet kendaraan tidak dapat dipakai kembali dan tidak larut di dalam tanah maupun air tanah, sehingga sangat membahayakan bagi lingkungan (Evaldo, 2014). Ban karet mengandung zat berbahaya seperti minyak extender $25 \%$ berasal dari benzena, stirena, turunan benzena, dan butadiena. Baik benzena dan butadiena, disinyalir merupakan racun yang membahayakan tubuh manusia (Fuzta, 2016). Oleh karena itu, perlu dilakukan usaha untuk mengurangi jumlah limbah ban bekas tersebut, salah satunya dengan digunakan sebagai bahan tambah campuran latasir. Penggunaan ban bekas sebagai bahan tambah (additive) aspal telah diteliti oleh $U S$ Department Of Transportation Federal Highway Administration di Amerika sejak tahun 1986. Hasilnya penggunaan ban hasil parutan ban bekas mampu mereduksi kerusakan pada perkerasan lentur yang diakibatkan oleh faktor cuaca dan lalulintas (AASHTO, 1982 sebagaimana dikutip Sugiyanto, 2008). Stabilitas campuran aspal karet menunjukkan lebih tinggi dari stabilitas campuran dengan aspal biasa. Secara umum karakteristik campuran aspal karet lebih baik dibandingkan dengan campuran menggunakan aspal biasa (Iriansyah, 1992 sebagaimana dikutip Darunifah, 2007)

Banyaknya limbah karet ban luar khususnya roda dua yang terserak dilokasi bengkel dan tempat tampal ban di Kota Jambi menjadikan menjadikan sampah yang terbuang dimana-mana. Berdasarkan banyaknya material karet ban luar yang belum termanfaatkan tersebut dan beberapa literatur peneliti akan melakukan pengujian dengan menggunakan limbah karet ban luar yang dihaluskan dengan cara karet ban diparut, lalu disaring dengan Saringan No. 16 kemudian dimasukkan kedalam aspal panas untuk campuran latasir dengan variasi penambahan yang berbeda. Dari penelitan ini diharapkan dapat meningkatkan kualitas aspal di dalam campuran latasir.

Permasalahan yang akan dibahas dalam penelitian ini yaitu bagaimana pengaruh penambahan limbah karet ban luar pada lapis tipis aspal pasir (latasir) terhadap Karakteristik Marshall.

\section{TINJAUAN PUSTAKA}

Silvia Sukirman, 2003 dalam FR Yamali, 2013. Aspal dapat diperoleh di alam maupun dari residu pengilangan minyak bumi, aspal adalah bahan material umum sebagai bahan pengikat agregat untuk itu bitumen sering pula disebut sebagai aspal. Banyak aspal dalam campuran aspal berkisar antara 4-10\% berdasarkan berat campuran atau $10-15 \%$ berdasarkan volume campuran.

Berbagai macam jenis aspal diantaranta latasir yang akan penulis telaah.

\section{Lapis Tipis Aspal Pasir}

Latasir atau lapis tipis aspal pasir merupakan lapis penutup permukaan perkerasan yang terdiri atas agregat halus atau pasir atau campuran keduanya, dan aspal keras yang dicampur, dihampar dan dipadatkan dalam keadaan panas pada temperatur tertentu. Spesifikasi Latasir telah dikembangkan sejak tahun 1983, yaitu dengan diterbitkannya pedoman berupa buku Petunjuk Pelaksanaan Lapis Tipis Aspal Pasir, yang dikembangkan oleh Departemen Pekerjaan Umum dengan No. 02/PT/B/1983. Selanjutnya dikembangkan pula standar nasional 
yaitu SNI 03-6749-2002, yang selanjutnya pula dilakukan revisi untuk lebih menyempurnakan secara substansial dan memenuhi kebutuhan dalam pekerjaan pembangunan jalan. Latasir terdiri atas 2 kelas: Latasir kelas A atau SS-1 (Sand Sheet-1) dengan ukuran nominal butir agregat atau pasir 9,5 $\mathrm{mm}$, dan Latasir kelas B atau SS-2 (Sand Sheet-2) dengan ukuran nominal butir agregat atau pasir 2,36 mm. Pada umumnya tebal nominal minimum untuk Latasir A dan Latasir B masing-masing $1,5 \mathrm{~cm}$ dan $2 \mathrm{~cm}$ dengan toleransi $\pm 2,0 \mathrm{~mm}$. Latasir pada umumnya digunakan untuk perencanaan jalan dengan lalu lintas tidak terlalu tinggi, tetapi dapat pula digunakan untuk pekerjaan pemeliharaan atau perbaikan sementara pada lalu lintas yang lebih tinggi.

Tabel 1. Ketentuan Sifat-Sifat Campuran Latasir Kelas A Dan Kelas B

\begin{tabular}{|l|l|l|}
\hline \multicolumn{2}{|l|}{ Sifat-sifat Campuran } & Latasir \\
\cline { 2 - 3 } & Kelas A \& B \\
\hline Penyerapan aspal (\%) & Maks. & 2,0 \\
\hline Jumlah tumbukan per bidang & & 50 \\
\hline & Min. & 3,0 \\
\cline { 2 - 3 } Rongga dalam campuran (\%) & Maks. & 6,0 \\
\hline Rongga dalam agregat (VMA) (\%) & Min. & 20 \\
\hline Rongga terisi aspal (\%) & Min. & 75 \\
\hline Stabilitas Marshall (kg) & Min. & 200 \\
\hline & Min. & 2 \\
\cline { 2 - 3 } Pelelehan (mm) & Maks. & 3 \\
\hline Marshall quotient (kg/mm) & Min. & 80 \\
\hline Stabilitas Marshall sisa (\%) setelah perendaman & & \\
selama 24 jam, $60^{\circ} \mathrm{C}$ & Min. & 90 \\
\hline
\end{tabular}

Sumber : Spesifikasi seksi 6.3 campuran beraspal panas (Revisi 3), 2010

\section{Fungsi Latasir}

Berdasarkan Petunjuk Pelaksanaan Latasir No. 02/PT/B/1983, Latasir mempunyai fungsi : a) Sebagai lapis penutup b) Sebagai lapisan aus c) Menyediakan permukaan jalan yang rata atau tidak licin

\section{Agregat}

Menurut Silvia Sukirman (2003), agregat merupakan butir-butir batu pecah, kerikil, pasir atau mineral lain, baik yang berasal dari alam maupun buatan yang berbentuk mineral padat berupa ukuran besar maupun kecil atau fragmen- fragmen. Agregat merupakan komponen utama dari struktur perkerasan jalan. Karakteristik agregat berpengaruh pada kekuatan struktur perkerasan jalan. Dengan demikian kualitas perkerasan jalan ditentukan juga dari sifat agregat dan hasil campuran agregat dengan material lain. Dalam Spesifikasi Umum 2010 (Revisi 3), agregat terbagi dalam 3 kelompok, yaitu :

a. Agregat kasar : bahan yang tertahan ayakan No. $4(4,75 \mathrm{~mm})$.

b. Agregat halus : bahan yang lolos ayakan No. 4 (4,75 mm).

c. Bahan pengisi (filler) : bahan yang lolos saringan No. $200(0,075 \mathrm{~mm})$

\section{a. Agregat Kasar}

Fraksi agregat kasar untuk rancangan adalah yang tertahan saringan No. 4 $(4,75 \mathrm{~mm})$ dan haruslah bersih, keras, awet dan bebas dari lempung atau bahan yang tidak dikehendaki lainnya dan memenuhi ketentuan yang diberikan.

\section{b. Agregat Halus}


Agregat halus dari sumber bahan manapun harus terdiri atas pasir atau hasil pengayakan batu pecah, dan terdiri atas bahan yang lolos ayakan No. 4 $(4,75 \mathrm{~mm})$.

\section{c. Bahan Pengisi (Filler)}

Bila diperlukan bahan pengisi harus dari semen portland. Bahan pengisi dapat juga menggunakan abu batu, abu terbang, atau material lainnya. Bahan tersebut harus bebas dari bahan yang tidak dikehendaki, mengandung bahan yang lolos ayakan 0,150 mm (No. 100) minimum 95\% dan lolos ayakan $0,075 \mathrm{~mm}$ (No. 200) minimum $75 \%$ terhadap beratnya, serta mempunyai sifat non plastis.

\section{d. Gradasi Agregat Gabungan}

Gradasi agregat gabungan untuk campuran aspal, ditunjukkan dalam persenterhadap berat agregat. Gradasi agregat diperoleh berdasarkan hasil pemeriksaan dengan menggunakan satu set saringan. Satu set saringan terdiri dari pan, ukuran saringan paling kasar hingga paling halus, dan pan. Ukuran saringan pada umumnya terdiri dari saringan berukuran 4 inci, 31/2 inci, 3 inci, 21/2 inci, 2 inci, $1 \frac{1}{2} 2$ inci, 1 inci, $3 / 4$ inci, $1 / 2$ inci, $3 / 8$ inci, No. 4 , No. 8 , No. 16 , No. 30 , No. 50 , No. 100, dan No. 200.

\section{Pengujian Marshall}

Konsep Marshall Test dikembangkan oleh Bruce Marshall, sorang insinyur perkerasan pada Mississipi State Highway. Pada Tahun 1948 Us Cops Of Enggineering meningkatkan dan menambah beberapa kriteria pada prosedur testnya, terutama kriteria rancangan campuran. Sejak saat itu test ini banyak diadopsi oleh berbagi organisasi dan pemerintahan dibanyak negara negara dengan bebrapa modifikasi prosedur ataupun intepretasi terhadap hasilnya. (Gusman, 2012)

Alat Marshall merupakan alat tekan yang dilengkapi dengan Proving ring (cincin penguji) berkapasitas $26,7 \mathrm{KN}$ (6000 lbf) dan Flowmeter. Proving ring digunakan untuk mengukur nilai stabilitas dan flowmeter untuk mengukur kelelehan plastis atau flow. Benda uji Marshall berbentuk silinder berdiameter 4 inchi $(10,2 \mathrm{~cm})$ dan tinggi 2,5 inchi $(6,35 \mathrm{~cm})$. Prosedur pengujian marshall mengikuti SNI 06-2489-1991, atau AASHTO T-245-90, atau ASTM d-155976. (Silvia Sukirman, 2007).

Prinsip dasar metode marshall adalah pemeriksaan stabilitas dan kelelehan (flow), serta analisis kepadatan dan pori dari campuran padat yang terbentuk. Menurut Sukirman tahun 2007, secara umum pengujian Marshall meliputi enam butir pengujian : a) Penentuan berat volume benda uji, b) Pengujian nilai stabilitas, c) Pengujian kelelehan (flow), d) Perhitungan Marshall Quotient.

\section{Karet Ban Luar}

Ban merupakan bagian roda yang langsung bersentuhan dengan jalan. Disaat sepeda motor berjalan dan berhenti akan terjadi gesekan antara ban dan permukaan jalan. Ban selain berfungsi untuk menopang berat motor dan pengendara pada area yang kecil dimana permukaan ban menyentuh permukaan jalan, menyalurkan gaya tekan pada saat pengendaraan dan pengereman, juga meredam kejutan secara simultan/terus menerus. (Jalius Jama, 2008). Pada dasarnya ban yang digunakan pada sepeda motor, umumnya terdiri atas dua bagian utama yaitu ban luar dan ban dalam. Konstruksi ban pada 
umumnya sama, baik ban dengan ban dalam maupun ban tanpa ban dalam. Ban bagian luar disebut Tread terbuat dari karet yang keras karena bersentuhan langsung dengan tanah. Untuk itu tread harus memiliki ketahan aus yang tinggi dan cukup baik melindungi ban dalam. Sedangkan lapisan bagian dalam ban disebut Breaker, carcas dan tread fungsinya menjaga dan melindungi ban bagian dalam dari tekanan udara dan pukulan dari luar secara bersamaan. Carcas ini terbuat dari lapisan kain (fabric layer) dengan bahan nilon dan rayon yang dilapisi karet dan kawat yang jumlah lapisannya menentukan kekuatan ban.

Disamping itu ada lapisan bead yang mampu memegang dengan kuat pada pelek melalui tekanan udara selama berjalan. Lapisan yang berbeda dibagian dalam dari ban tubeless (tanpa ban dalam) yang bersifat elastis, jika tertusuk paku udara bagian dalam tidak bocor keluar.

\section{Bahan Baku}

Menurut (Tri Kuncoro Putro, 1992). Dalam proses pembuatan ban, diperlukan bahan baku yaitu:

a) Karet merupakan bahan dasar utama dalam pembuatan ban. Karet dapat dibedakan menjadi dua macam ditinjau dari asalnya, yaitu : Karet alam (natural rubber) dan karet buatan (synthetic rubber)

b) Kawat

c) Nylon

d) Bahan pengisi

\section{HASIL DAN PEMBAHASAN}

\section{Pemeriksaan Sifat Fisik Agregat}

Hasil pemeriksaan agregat disajikan dalam bentuk tabel. Metode pengujian masing-masing agregat dilakukan dengan acuan menggunakan Standar Nasional Indonesia (SNI) dan persyaratan mutu bahan sesuai standar Spesifikasi Teknis 2010 Revisi 3 Divisi 6. Pengujian ini meliputi : pengujian agregat kasar, halus, dan filler.

\section{Hasil Pemeriksaan Sifat Fisik Aspal + Karet Ban Luar}

Pengujian untuk aspal dengan variasi karet dilakukan untuk mengetahui perubahan karakteristik aspal setelah dilakukan penambahan karet dari $0 \%$, $1 \%, 2 \%, 3 \%, 4 \%$, dan 5\% terhadap berat aspal. Pengujian aspal dengan variasi kadar karet hanya dilakukan untuk pengujian penetrasi dan berat jenis aspal.

Tabel 2. Pengujian Aspal Pen. 60/70 dengan Karet Ban Luar

\begin{tabular}{|c|c|c|c|c|c|c|c|c|}
\hline \multirow{2}{*}{ No. } & \multirow{2}{*}{ Jenis Pengujian } & \multicolumn{6}{|c|}{ Variasi Kadar Karet dalam Aspal (\%) } & \multirow{2}{*}{$\begin{array}{c}\text { Metode Uji/ } \\
\text { Standar }\end{array}$} \\
\hline & & 0 & 1 & 2 & 3 & 4 & 5 & \\
\hline 1. & Berat Jenis & 1,0381 & 1,0343 & 1,0355 & 1,0359 & 1,0376 & 1,0376 & SNI 06-2441-1991 \\
\hline 2. & $\begin{array}{l}\text { Penetrasi; } 25^{\circ} \mathrm{C}, 100 \\
\text { g; } 5 \text { detik; } 0,1 \mathrm{~mm}\end{array}$ & 68,000 & 72,500 & 69,875 & 68,250 & 66,375 & 62,750 & SNI 06-2456-2011 \\
\hline
\end{tabular}

\section{Sumber : Hasil Penelitian di Laboratorium, 2017}

Pada Tabel 2 diatas dapat dilihat bahwa perbandingan nilai penetrasi aspal yang mengalami penambahan karet mengalami penurunan prosentase dari nilai penetrasi aspal murni, pada variasi kadar $1 \%$ sempat mengalami penaikan, tetapi 
semakin bertambahnya kadar karet nilai penetrasi aspal mengalami penurunan, ini semua karena didalam aspal terdapat benda padat yang menahan jarum penetrasi.

\section{Pengujian Marshall (Tahap 1)}

Dari pemeriksaan dan pengujian-pengujian Marshall yang dilakukan, maka diperoleh nilai-nilai Karakteristik Marshall, sebagai berikut :

Tabel 3. Pengujian Marshall Latasir A (Standar)

\begin{tabular}{|c|c|c|c|c|c|c|c|}
\hline \multirow{3}{*}{ No. } & \multirow{3}{*}{ Karakteristik Marshall } & \multirow{3}{*}{ Syarat } & \multicolumn{5}{|c|}{ Pengujian Marshall Latasir A (Standar) } \\
\hline & & & \multicolumn{5}{|c|}{ Variasi Kadar Aspal ( \% ) } \\
\hline & & & 7 & 8 & 9 & 10 & 11 \\
\hline 1 & Berat Isi ( gr/cc ) & - & 2,261 & 2,474 & 2,282 & 2,289 & 2,290 \\
\hline 2 & VMA $(\%)$ & Min. 20 & 22,451 & 24,364 & 23,396 & 24,030 & 24,812 \\
\hline 3 & $\operatorname{VIM}(\%)$ & $3-6$ & 9,985 & 9,898 & 6,354 & 4,708 & 3,237 \\
\hline 4 & VFA $(\%)$ & Min. 75 & 57,643 & 62,157 & 75,680 & 83,584 & 90,274 \\
\hline 5 & Stabilitas Marshall (Kg) & Min. 200 & 637,684 & 628,004 & 502,673 & 561,088 & 635,496 \\
\hline 6 & Flow (mm) & $2-3$ & 2,015 & 2,201 & 2,159 & 2,489 & 4,530 \\
\hline 7 & Marshall Quotient (Kg/mm) & Min. 80 & 318,369 & 287,025 & 236,914 & 225,176 & 160,324 \\
\hline
\end{tabular}

Sumber: Hasil Penelitian di Laboratorium, 2017

Dari tabel diatas dapat dilihat nilai karakteristik Campuran Marshall Latasir A (standar) tanpa menggunakan karet ban luar, pada beberapa kadar aspal tidak memenuhi persyaratan campuran marshall Latasir A pada Spesifikasi Teknis 2010 Revisi 3.

\section{Penentuan Kadar Aspal Optimum}

Untuk menentukan kadar aspal optimum harus seluruh parameter Marshall yang disyaratkan dapat terlihat kadar aspal yang paling memenuhi syarat sesuai dengan Spesifikasi Teknis 2010 Revisi 3, terletak pada rentang kadar aspal $9,6 \%-10,0 \%$.

\section{Komposisi Campuran Latasir A dengan Karet Ban Luar}

Penambahan karet ban adalah prosentase karet ban terhadap berat kadar aspal optimum, berdasarkan perhitungan kadar aspal optimum yang didapat adalah 9,8\%, maka untuk mendapatkan berat dari masing-masing prosentase karet ban, yaitu

Berat Aspal terhadap campuran $=9,8 \% \times 1200$ gram $=117,6$ gram

Berat karet ban terhadap aspal $=1 \% \times 117,6$ gram $=1,176$ gram Untuk perhitungan Campuran Latasir A dengan penambahan karet ban luar sebagai berikut :

a) Kadar Karet Ban $0 \%$

$$
\begin{aligned}
& \text { B. P. } 0,5-1=36,15 \% \times 90,20 \% \times 1200=391,23 \text { gram } \\
& \text { Pasir }=19,00 \% \times 90,20 \% \times 1200=205,66 \text { gram } \\
& \text { Abu Batu }=44,85 \% \times 90,20 \% \times 1200=485,51 \text { gram } \\
& \text { Karet Ban }=0,00 \% \times 117,6=0,00 \text { gram } \\
& \text { Aspal }=9,80 \% \times 1200-0,00=117,60 \text { gram } \\
& \text { Total }=1200,00 \text { gram }
\end{aligned}
$$


b) Kadar Karet Ban $1 \%$

\begin{tabular}{|c|c|c|c|c|c|c|c|c|}
\hline B. P. $0,5-1$ & $=$ & $36,15 \%$ & $x$ & $90,20 \%$ & $x$ & 1200 & $=$ & 391,23 gram \\
\hline Pasir & $=$ & $19,00 \%$ & $x$ & $90,20 \%$ & $x$ & 1200 & $=$ & 205,66 gram \\
\hline Abu Batu & $=$ & $44,85 \%$ & $x$ & $90,20 \%$ & $x$ & 1200 & $=$ & 485,51 gram \\
\hline Karet Ban & $=$ & & & $1,00 \%$ & $x$ & 117,6 & $=$ & 1,18 gram \\
\hline Aspal & $=$ & $9,80 \%$ & $x$ & 1200 & - & 1,18 & $=$ & 116,42 gram \\
\hline & & & & & & Total & $=$ & 1200,00 gram \\
\hline
\end{tabular}

c) Kadar Karet Ban $2 \%$

$$
\begin{aligned}
& \text { B. P. } 0,5-1=36,15 \% \times 90,20 \% \times 1200=391,23 \text { gram } \\
& \text { Pasir }=19,00 \% \times 90,20 \% \times 1200=205,66 \text { gram } \\
& \mathrm{Abu} \text { Batu }=44,85 \% \times 90,20 \% \times 1200=485,51 \text { gram } \\
& \text { Karet Ban }=2,00 \% \times 117,6=2,35 \text { gram } \\
& \text { Aspal }=9,80 \% \times 1200-2,35=115,25 \text { gram } \\
& \text { Total }=1200,00 \text { gram }
\end{aligned}
$$

d) Kadar Karet Ban $3 \%$

$$
\begin{aligned}
& \text { B. P. } 0,5-1=36,15 \% \times 90,20 \% \times 1200=391,23 \text { gram } \\
& \text { Pasir }=19,00 \% \times 90,20 \% \times 1200=205,66 \text { gram } \\
& \text { Abu Batu }=44,85 \% \times 90,20 \% \times 1200=485,51 \mathrm{gram} \\
& \text { Karet Ban } \quad 3,00 \% \times 117,6=3,53 \text { gram } \\
& \text { Aspal }=9,80 \% \times 1200-3,53=114,07 \text { gram } \\
& \text { Total }=1200,00 \text { gram }
\end{aligned}
$$

e) Kadar Karet Ban $4 \%$

$$
\begin{aligned}
& \text { B. P. } 0,5-1=36,15 \% \times 90,20 \% \times 1200=391,23 \text { gram } \\
& \text { Pasir } \quad=19,00 \% \times 90,20 \% \times 1200=205,66 \text { gram } \\
& \text { Abu Batu }=44,85 \% \times 90,20 \% \times 1200=485,51 \text { gram } \\
& \text { Karet Ban } \quad 4,00 \% \times 117,6=4,70 \text { gram } \\
& \text { Aspal }=9,80 \% \times 1200-4,70=112,90 \text { gram } \\
& \text { Total }=1200,00 \text { gram }
\end{aligned}
$$

f) Kadar Karet Ban $5 \%$

$$
\begin{aligned}
\text { B. P. 0,5-1 } & =36,15 \% \times 90,20 \% \times 1200=391,23 \text { gram } \\
\text { Pasir } & =19,00 \% \times 90,20 \% \times 1200=205,66 \text { gram } \\
\text { Abu Batu } & =44,85 \% \times 90,20 \% \times 1200=485,51 \text { gram } \\
\text { Karet Ban } & =5,00 \% \times 117,6=5,88 \text { gram } \\
\text { Aspal } & =9,80 \% \times 1200 \times-5,88=11,72 \text { gram } \\
&
\end{aligned}
$$

\section{Pengujian Marshall (Tahap 2)}

Dari pemeriksaan dan pengujian-pengujian Marshall yang dilakukan, maka diperoleh nilai-nilai Karakteristik Marshall, sebagai berikut :

Tabel 4. Hasil Pengujian Marshall Latasir A (Dengan Karet Ban Luar) 


\begin{tabular}{|c|l|c|c|c|c|c|c|c|}
\hline \multirow{2}{*}{ No. } & \multirow{3}{*}{ Karakteristik Marshall } & \multirow{6}{*}{ Syarat } & \multicolumn{5}{|c|}{ Pengujian Marshall Latasir A } \\
\cline { 4 - 9 } & & & \multicolumn{5}{|c|}{ Variasi Kadar Karet dalam Aspal ( \% ) } \\
\cline { 4 - 9 } & & & 0 & 1 & 2 & 3 & 4 & 5 \\
\hline 1 & Berat Isi ( gr/cc ) & - & 2,275 & 2,275 & 2,272 & 2,245 & 2,248 & 2,247 \\
\hline 2 & VMA (\%) & Min. 20 & 24,308 & 24,223 & 24,239 & 25,072 & 24,876 & 24,841 \\
\hline 3 & VIM (\%) & $3-6$ & 5,542 & 5,600 & 5,888 & 7,172 & 7,201 & 7,398 \\
\hline 4 & VFA (\%) & Min. 75 & 80,150 & 79,557 & 78,415 & 74,060 & 73,760 & 72,895 \\
\hline 5 & Stabilitas Marshall (Kg) & Min. 200 & 618,072 & 462,775 & 480,031 & 433,231 & 633,307 & 454,400 \\
\hline 6 & Flow (mm) & $2-3$ & 2,604 & 3,306 & 3,649 & 4,432 & 4,509 & 4,487 \\
\hline 7 & Marshall Quotient (Kg/mm) & Min. 80 & 252,044 & 141,203 & 135,223 & 98,288 & 141,766 & 103,336 \\
\hline 8 & Stabilitas Sisa (\%) & Min. 90 & 92,074 & 91,368 & 90,608 & 90,489 & 87,164 & 92,357 \\
\hline
\end{tabular}

Sumber : Hasil Penelitian di Laboratorium, 2017

Dari tabel diatas dapat dilihat nilai karakteristik Campuran Marshall Latasir A dengan menggunakan karet ban luar, mengalami perubahan sifat-sifat campuran aspal.

Pada gambar diatas terlihat nilai VMA pada masing- masing kadar aspal mengalami peningkatan dan melebihi dari batas miminum yang disyaratkan yaitu $20 \%$, Nilai VIM penambahan karet diatas $2 \%$ berada diatas ambang batas syarat, semakin bertambahnya kadar karet dalam aspal menyebabkan nilai VFA semakin turun karena rongga udara dalam campuran terisi oleh karet ban yang masih dalam keadaan benda padat, sehingga aspal kurang terisi dengan sempurna. Nilai stabilitas aspal tidak terjadi perubahan yang signifikan kecuali pada kadar karet $4 \%$ yang terjadi peningkatan, tetapi nilai stabilitas seluruh kadar karet dalam aspal masih memenuhi batas minimum nilai stabilitas yang disyaratkan, yaitu $200 \mathrm{Kg}$. Nilai flow mengalami kenaikkan yang stabil, walau tidak memenuhi syarat standar Spesifikasi Teknis 2010 Revisi 3, karena terjadi penambahan karet ban dalam campuran.

Semakin tingginya nilai flow, karena penambahan karet ban akan membuat campuran aspal memiliki tingkat kelenturan yang cukup besar, sehingga kemampuan deformasi atau perubahan bentuk campuran aspal semakin lama. Terlihat bahwa nilai MQ semakin rendah, membuat campuran tidak kaku atau semakin lembek, menyebabkan kemampuan aspal untuk menyesuaikan diri akibat lendutan semakin baik atau nilai kelenturan meningkat. Tingkat kelenturan yang bagus akibat penambahan karet terletak pada kadar karet 3\%. Nilai Indeks Stabilitas Sisa adalah ukuran untuk memprediksi sifat keawetan (durabilitas) campuran. Semakin besar nilai nilai indeks stabilitas sisa (Sa) maka mengindikasikan bahwa campuran bersifat porus sehingga air mudah masuk dalam campuran yang selanjutnya merusak ikatan aspal dan agregat. Dari hasil penelitian tampak penurunan nilai Sa yang dihasilkan stabil, sehingga air tidak mudah masuk ke dalam campuran yang terdapat karet.

Parameter Marshall campuran Latasir A yang sesuai dengan Spesifikasi Teknis 2010 Revisi 3, kecuali nilai flow karena melebihi standar yang disyaratkan. Terlihat pada kadar karet dalam aspal optimum terletak pada rentang kadar karet dalam aspal $0 \%-2 \%$, tetapi karena mulai dilakukan penambahan karet pada variasi $1 \%$, maka kadar karet dalam aspal yang optimum terletak pada rentang $1 \%-2 \%$. 


\section{KESIMPULAN}

1. Keseluruhan material bahan baik agregat kasar, agregat halus, filler, dan aspal Pen. 60/70 telah memenuhi syarat untuk campuran Lapis Tipis Aspal Pasir Kelas A pada Spesifikasi Teknis 2010 Revisi 3 Divisi 6.

2. Sebelum dilakukan Pengujian Marshall awal, maka dilakukan pengujian Aspal Pen. 60/70 (Kadar Karet 0\%) dengan variasi penambahan karet ban luar sebesar 1\%, 2\%, 3\%, 4\%, dan 5\%. Pengujian Aspal Pen 60/70 dengan penambahan karet terbatas pengujian berat jenis aspal dan penetrasi aspal. Hasil dari pengujian Aspal Pen. 60/70 mengalami penurunan berat jenis sehingga aspal dengan penambahan karet ban luar menjadi ringan. Sedangkan penetrasi aspal dengan penambahan karet ban luar mengalami penurunan nilai prosentase, meskipun terjadi peningkatan di kadar karet $1 \%(72,5 \mathrm{~mm})$, tetapi pada kadar karet 2\% hingga $5 \%$ mengalami penurunan menjadi $62,75 \mathrm{~mm}$.

3. Pengujian Marshall awal untuk mendapatkan nilai Kadar Aspal Optimum (KAO) dengan variasi kadar aspal 7\%, 8\%, 9\%, 10\%, dan 11\%. Setelah dilakukan pengujian, maka didapatkan seluruh karakteristik Marshall dengaan persyaratan sesuai Spesifikasi Teknis 2010 Revisi 3 yang memenuhi persyaratan tersebut terletak pada rentang 9,6\% dan $10 \%$. Nilai kadar aspal optimum optimum didapatkan dari nilai tengah dari rentang kadar aspal yang memenuhi persyaratan tersebut, yaitu 9,8\%.

4. Pengujian Marshall selanjutnya dengan menggunakan variasi dari karet ban luar $1 \%, 2 \%, 3 \%, 4 \%$, dan 5\%. Pada pengujian menggunakan karet ban terjadi perubahan karakteristik Marshall, tingkat kelenturan dan keawetan yang lebih baik, tetapi terdapat rongga udara yang banyak atau nilai VIM yang besar, sehingga nilai VFA menjadi kecil. Dari seluruh kadar karet dalam aspal yang memiliki tingkat kelenturan yang bagus pada kadar karet $3 \%$, tetapi yang memenuhi seluruh syarat Spesifikasi Teknis 2010 Revisi 3 pada kadar karet $1,5 \%$.

\section{Saran}

1. Perlu ketelitian dalam pekerjaan pembuatan benda uji agar dapat hasil yang lebih baik.

2. Perlu dilakukan penelitian lebih lanjut dengan kadar karet $0 \%$ sampai $3 \%$ dengan kenaikan $0,5 \%$.

3. Perlu pengujian yang lebih lanjut tentang pengaruh karet ban luar motor terhadap aspal.

\section{DAFTAR PUSTAKA}

Darunifah, Nurkhayati. 1992. Pengaruh Bahan Tambahan Karet Padat Terhadap Karakteristik Campuran Hot Rolled Sheet Wearing Course ( HRS - WC ). Semarang : Universitas Diponegoro.

Departemen Pekerjaan Umum. 1983. Petunjuk Pelaksanaan Lapis Tipis Aspal Pasir (lATASIR) No. 02/PT/B/1983.

Departemen Pekerjaan Umum. 2014. Spesifikasi Umum 2010 (Revisi 3) Tentang Pekerjaan Konstruksi Untuk Jalan Dan Jembatan. Jakarta.

Evaldo, Berry. 2014. Perancangan Laboratorium Pengaruh Penggunaan Bahan Tambah Crumb Rubber Untuk Memodifikasi Aspal Pada Campuran Asphalt Concrete Binder Course (AC-BC). Yogyakarta : Universitas Gadjah Mada.

Fuzta, Alfin. 2016. Internasionalisasi Kerajinan pada Bengkel Sapuban Bekas (Studi Kasus Pada Komunitas Sapu, Kelurahan Randuacir, 
Kecamatan Argomulyo, Kota Salatiga). Kota Salatiga : Universitas Kristen Satya Wacana.

Jalius Jama, dkk. 2008. Teknik Sepeda Motor Jilid 3. Jakarta : Direktorat Pembinaan Sekolah Menengah Kejuruan

Kumpulan Parameter Uji Lab Unbari dengan standar Badan Standarisasi Nasional (BSN) 1990.

Kumpulan Parameter Uji Lab Unbari dengan standar Badan Standarisasi Nasional (BSN) 1991.

Kumpulan Parameter Uji Lab Unbari dengan standar Badan Standarisasi Nasional (BSN) 1998.

Kumpulan Parameter Uji Lab Unbari dengan standar Badan Standarisasi Nasional (BSN) 2008.

Sugiyanto, Gito. 2008. Kajian Karakteristik Campuran Hot Rolled Asphalt Akibat Penambahan Limbah Seruk Ban Bekas. Purwokerto : Universitas Soedirman.

Sukirman, Silvia. 2003. Beton Aspal Campuran Panas. Bandung : Nova.

Tri Kuncoro Putro, Frederikus. 1992. Perencanaan Ketel Uap Untuk Proses Pembuatan Ban. Semarang : Universitas Diponegoro.

Tristianto, Andika Budi, dkk. 2011. Pengaruh Penambahan 'Limbah Karet Ban Luar' Terhadap Karakteristik Marshall Pada Lapis Tipis Aspal Pasir (Latasir) Kelas B. Kota Malang : Universitas Muhammadiyah Malang.

Yamali FR, 2013, "Pengaruh Variasi Suhu Pemadatan Terhadap Karakteristik Campuran Split Mastic Asphalt 0/11” Journal Teknik Sipil ISSN 20889321 Universitas Syiah Kuala Banda Aceh. 